\title{
Experimental field data for modeling the growth response of tef to nitrogen fertilizer and water stress
}

\author{
K. Paff ${ }^{*}$, S. Asseng ${ }^{1}$, A. Araya ${ }^{2}$, J. Davison ${ }^{3}$, Asfaw Abebe Getu ${ }^{4}$, and Okubay Giday ${ }^{5}$ \\ ${ }^{1}$ University of Florida, Department of Agricultural and Biological Engineering, 1741 Museum Road, \\ Gainesville, FL, 32611-0570, USA \\ 2 Kansas State University, Southwest Research Extension Center, 4500 E Mary St, Garden City, KS 67846 \\ USA \\ ${ }^{3}$ Retired, University of Nevada Cooperative Extension Churchill County, 111 Sheckler Road, Fallon, NV \\ 89406-8951 USA \\ ${ }^{4}$ Sirinka Agricultural Research Center, P.O. Box 74, Woldia, Ethiopia \\ ${ }^{5}$ Department of Land Resource Management and Environmental Protection, Mekelle University, P.O. Box \\ 213 Mekelle, Ethiopia \\ * e-mail: kpaff@ufl.edu
}

\begin{abstract}
Field data from six experiments covering a wide range of growing conditions were organized for tef growth and cropping systems modeling. The data included (i) an irrigation experiment at Mekelle and Ilala, Ethiopia, (ii) a cultivar trial at Fallon, NV, USA, (iii) a nitrogen fertilizer experiment in the Jamma District of Ethiopia, (iv) a nitrogen fertilizer experiment in the Ofla District of Ethiopia, (v) a nitrogen fertilizer experiment at Ude and Kajima, Ethiopia, and (vi) a nitrogen fertilizer experiment at Gare Arera, Ethiopia. The combined data set covered 40 experimental treatments and 131 observations. Time series data were limited to biomass data from two treatments from the Tigray region experiment. All other crop related data was measured at maturity. Daily weather data was taken primarily from satellite weather databases for Ethiopia, and from weather stations in the USA. These data have been used in various agronomic studies, as well as the calibration of the DSSAT Tef model. The results of this model calibration are also included in this paper. The objective of this paper was to present and preserve all of the field data used for calibrating the DSSAT Tef model, as well as the tef model's simulations of the field data.
\end{abstract}

Keywords: Crop Model, Teff, Eragrostis tef, DSSAT

1 INTRODUCTION: Field experimental data were assembled for calibrating the Decision Support System for Agrotechnology Transfer (DSSAT) Tef model. The field experimental data were selected from a range of published tef field experiments conducted in Mekelle, Ilala, Jamma District, Ofla District, Ude, Kajima, and Gare Arera, Ethiopia, as well as in Fallon, NV, USA. The climates for the experiments ranged from cool and semi-arid to hot and arid.

The data consists of 40 treatments and 131 replications. Model ready field data for tef is extremely rare and all of the experiments used were missing at least some data needed for crop modeling that had to be filled in from other sources. All of the data sets included grain yield data. Of the six experiments, one included days to emergence, four included days to heading or anthesis, five included days to maturity, five included total aboveground biomass at maturity, 3 included grain nitrogen at maturity, 2 included straw nitrogen at maturity, and 3 included total aboveground nitrogen at maturity. Reported crop management data included planting date, plant population density, fertilizer and irrigation rates and dates, and soil water and fertility information. Not all experiments reported all of this data, however. Agronomic management ranged from rainfed without fertilizer (sub-optimal) to irrigated with recommended fertilizer rates (optimal). Pests and diseases were controlled for most of the experiments.

The datasets represent low to high yielding growing conditions for tef. The observed grain yields across the various growing environments and management practices ranged from 350 to $3013 \mathrm{~kg} / \mathrm{ha}$ (Table 1). The lowest yield was observed for the rainfed treatment at llala, Ethiopia (Araya et al., 2010). The highest yield was observed for the $69 \mathrm{~kg} \mathrm{~N} / \mathrm{ha}$ treatment in the Ofla District in Ethiopia (Okubay, 2012). Both of these locations were cool and semi-arid with distinct rainy seasons. 
Assembled data were quality checked and individually and partly published in earlier studies (Araya et al., 2010; Asfaw, 2012; Davison and Laca, 2010; Okubay, 2012; Tulema et al., 2007; Tulema et al., 2005). Not all experiments or treatments from the studies were used in this paper. All soil profiles were standardized to a depth of $210 \mathrm{~cm}$. Soil data for the Ethiopian sites came from the experiments. Soil data from the American site came from the NRCS soil survey (NRCS, 2016). The objective of this paper was to present and preserve all of the field data used for calibrating the DSSAT Tef model, as well as the tef model's simulations of the field data.

Table 1. Summary of experiments and ranges of observed grain yields of tef adjusted to $0 \%$ grain moisture across diverse treatments

\begin{tabular}{|c|c|c|c|}
\hline Experiments & Location & $\begin{array}{l}\text { Number of } \\
\text { treatments }\end{array}$ & $\begin{array}{l}\text { Observed yield } \\
\text { range (kg/ha) }\end{array}$ \\
\hline $\begin{array}{l}\text { Water deficit experiment with } \\
\text { different irrigation rates }\end{array}$ & Mekelle and Ilala, Ethiopia & 9 & $350-1950$ \\
\hline Cultivar trial & Fallon, NV, USA & 15 & $483-1729$ \\
\hline Nitrogen application rate and type & Jamma District Ethiopia & 5 & $665-2222$ \\
\hline Nitrogen application rate and type & Ofla District, Ethiopia & 5 & $1847-3013$ \\
\hline $\begin{array}{l}\text { Nitrogen application across two } \\
\text { locations }\end{array}$ & $\begin{array}{l}\text { Ude } 1 \text { and Kajima, } \\
\text { Ethiopia }\end{array}$ & 2 & $772-1925$ \\
\hline $\begin{array}{l}\text { Nitrogen application type across } \\
\text { two soils }\end{array}$ & Gare Arera, Ethiopia & 4 & $352-1496$ \\
\hline
\end{tabular}

2 IRRIGATION EXPERIMENT-MEKELLE AND ILALA, ETHIOPIA: An experiment with five different irrigation treatments that varied in timing and quantity was conducted during the growing season of 2008 and an experiment with three different irrigation treatments that varied in timing and quantity was conducted during the growing season of 2009 at Mekelle (13 $3^{\prime} \mathrm{N}$ and $39^{\circ} 6^{\prime} \mathrm{E}$ ), in the Tigray Region of Ethiopia, on a Cambisol soil (Araya et al., 2010). An experiment with one rainfed treatment was conducted during the growing season of 2008 at llala ( $13^{\circ} 4^{\prime} \mathrm{N}$ and $39^{\circ} 4^{\prime} \mathrm{E}$ ), in the Tigray Region of Ethiopia, on a Vertisol soil (Araya et al., 2010). The tef cultivars DZ-974 (improved) and keyh (local) were sown on August $2^{\text {nd }}, 2008$ and August $5^{\text {th }}, 2008$ at the Mekelle and llala sites respectively. The keyh variety was sown on July $31^{\text {st }}$, 2009 at the Mekelle site. All treatments had $60 \mathrm{~kg} \mathrm{~N} / \mathrm{ha}$ and $46 \mathrm{~kg} \mathrm{P} / \mathrm{ha}$ applied in a split application, with half of the $\mathrm{N}$ fertilizer applied at planting and the other half applied 30 days after planting. Irrigation treatments ranged from 0 to 9 irrigations and 0 to $95 \mathrm{~mm}$ applied water, depending on the year and the location (Table 2). Aboveground dry matter and grain yield were measured at maturity. Times series data for aboveground dry matter was measured in 2008 for the rainfed and 8 irrigation treatments at Mekelle.

\begin{tabular}{|c|c|c|c|c|c|c|}
\hline \multirow{3}{*}{$\begin{array}{l}\text { Irrigation dates (yyyy-mm-dd) } \\
\text { Mekelle, } 2008\end{array}$} & \multicolumn{6}{|c|}{ Irrigation (mm) } \\
\hline & \multicolumn{5}{|c|}{ Irrigation Treatments } & \\
\hline & 10 & 12 & 14 & 16 & 18 & 19 \\
\hline 2008-09-17 & 0 & 10 & 10 & 10 & 10 & - \\
\hline 2008-09-19 & 0 & 10 & 10 & 10 & 10 & - \\
\hline 2008-09-21 & 0 & 0 & 12 & 12 & 12 & - \\
\hline $2008-09-24$ & 0 & 0 & 15 & 15 & 15 & - \\
\hline 2008-09-29 & 0 & 0 & 0 & 12 & 12 & - \\
\hline 2008-10-03 & 0 & 0 & 0 & 12 & 12 & - \\
\hline $2008-10-07$ & 0 & 0 & 0 & 0 & 12 & - \\
\hline 2008-10-09 & 0 & 0 & 0 & 0 & 12 & - \\
\hline Total Irrigation (mm) & 0 & 20 & 45 & 69 & 95 & - \\
\hline
\end{tabular}


Table 2. Irrigation dates and amount for water deficit experiment-Tigray Region, Ethiopia (Continued)

\begin{tabular}{lcccccc}
\hline Irrigation dates (yyyy-mm-dd) & \multicolumn{7}{c}{ Irrigation $\mathbf{( m m}$ ) } \\
\hline Mekelle, 2009 & 10 & 12 & 14 & 16 & 18 & 19 \\
\hline $2009-09-17$ & 0 & - & 10 & - & - & 10 \\
$2009-09-19$ & 0 & - & 10 & - & - & 10 \\
$2009-09-20$ & 0 & - & 10 & - & - & 10 \\
$2009-09-24$ & 0 & - & 10 & - & - & 10 \\
$2009-09-27$ & 0 & - & 0 & - & - & 10 \\
$2009-10-01$ & 0 & - & 0 & - & - & 10 \\
$2009-10-03$ & 0 & - & 0 & - & - & 10 \\
$2009-10-05$ & 0 & - & 0 & - & - & 10 \\
$2009-10-07$ & 0 & - & 0 & - & - & 10 \\
\hline Total Irrigation $(\mathbf{m m})$ & 0 & - & 40 & - & - & 90 \\
\hline
\end{tabular}

3 YIELD TRIAL EXPERIMENT-FALLON, NV, USA: Field trials were conducted with 15 different tef cultivars planted on June $4^{\text {th }}, 2009$ in Fallon, NV, USA $\left(39^{\circ} 29^{\prime} 20^{\prime \prime} \mathrm{N}, 118^{\circ} 49^{\prime} 41^{\prime \prime}\right.$ W) on a Dia loam soil (Davison and Laca, 2010). The cultivars used were Dessie, 347362, 494432, 193508, 273889, Uk. Brown, 557457, 494366, Uk. White, 193514, 195932, 494479, 494465, 329680, and 494433. No fertilizer use was reported. The plots were regularly flood irrigated between June $13^{\text {th }}$ and harvest. The plots were sprayed with an herbicide to control broadleaved weeds on July $9^{\text {th }}$ and regularly hand weeded. The grain yield at maturity was reported, but the total biomass was not reported.

4 NITROGEN FERTILIZER EXPERIMENT-JAMMA DISTRICT, ETHIOPIA: Field experiments with four nitrogen fertilizer rates and two types of nitrogen fertilizer were conducted during the growing season of 2011 in the Jamma District $\left(10^{\circ} 27^{\prime} \mathrm{N}, 39^{\circ} 15^{\prime} \mathrm{E}\right)$ of Ethiopia (Asfaw, 2012). The original purpose of this study was to describe the study area soil and to compare the efficiency of slow release nitrogen fertilizer and conventional urea at increasing the yield and yield traits of wheat and tef. This data set only includes the slow release fertilizer treatments for tef. The soil type was a Vertisol (clay soil). The tef cultivar used was a local variety called Wajera. The slow release nitrogen rates ranged from $0 \%$ of the recommended rate to $150 \%$ of the recommended rate (Table 3 ). All slow release nitrogen was applied at planting, but the exact planting date was not provided in the publication. The planting date was assumed to be July $24^{\text {th }}$, 2011 based on the typical planting time frame for tef. The experiment measured the grain weight, straw weight, total aboveground biomass, grain $\mathrm{N}$ uptake, straw $\mathrm{N}$ uptake, and total aboveground $\mathrm{N}$ uptake at maturity.

\begin{tabular}{lc}
\hline \multicolumn{2}{l}{ Table 3. Summary of nitrogen fertilizer treatment experiment in the Jamma District of Ethiopia } \\
\hline Fertilizer Type & N Applied (kg/ha) \\
Urea Super Granule & 0 \\
Urea Super Granule & 23 \\
Urea Super Granule & 46 \\
Urea Super Granule & 69 \\
\hline
\end{tabular}

5 NITROGEN FERTLIZER EXPERIMENT-OFLA DISTRICT, ETHIOPIA: Field experiments with four nitrogen fertilizer rates and two types of nitrogen fertilizer were conducted during the growing season of 2011 in the Ofla District (12 31' 58" N, 39 30' 13" E) of Ethiopia (Okubay, 2012). The original purpose of this study was to describe the study area soil, to compare the performance of slow release nitrogen fertilizer and conventional urea for wheat and tef production, and to find the optimum slow release urea fertilizer rate for wheat and tef. This data set only includes the slow release fertilizer treatments for tef. The soil type was a Vertisol (clay soil). The tef cultivar used was an improved variety called DZ-cr-387, also known as Kuncho. The slow release nitrogen rates ranged from $0 \%$ of the recommended rate to $150 \%$ of the recommended rate (Table 4). All slow release nitrogen was applied at planting, but the exact planting date was not provided in the publication. The planting date was assumed to be July $24^{\text {th }}, 2011$ based on the typical planting time 
frame for tef. The experiment was rainfed. The experiment measured the grain weight, straw weight, total aboveground biomass, grain $\mathrm{N}$ uptake, straw $\mathrm{N}$ uptake, and total aboveground $\mathrm{N}$ uptake at maturity.

\begin{tabular}{lc}
\hline \multicolumn{2}{l}{ Table 4. Summary of nitrogen fertilizer treatment experiment in the Ofla District of Ethiopia } \\
\hline Fertilizer Type & N Applied (kg/ha) \\
Urea Super Granule & 0 \\
Urea Super Granule & 23 \\
Urea Super Granule & 46 \\
Urea Super Granule & 69 \\
\hline
\end{tabular}

6 NITROGEN FERTILIZER EXPERIMENT-UDE AND KAJIMA, ETHIOPIA: Field experiments measuring the fertilizer $\mathrm{N}$ use efficiency of tef were conducted at three sites in the Ada Area ( $8^{\circ} 48^{\prime} \mathrm{N}, 39^{\circ} 38^{\prime} \mathrm{E}$ ) of the Oromiya Region in Ethiopia in 1997 with a constant fertilizer rate (Tulema et al., 2005). The Ude 2 site was not included in this data set, however, due to high weed pressure (Tulema et al., 2005), which the DSSAT model cannot account for. The soil types at the Ude 1 and Kajima locations were a Vertisol and an Andisol respectively. The recommended fertilizer rate of $64 \mathrm{~kg} \mathrm{~N}$ and $20 \mathrm{~kg} \mathrm{P}$ per hectare was used at all locations. The experiment was rainfed. Planting occurred on July $22^{\text {nd }}$ and $23^{\text {rd }}$. The cultivar used was DZ-01-354. Dry matter yield, grain yield, and total $\mathrm{N}$ yield were measured at maturity.

7 ORGANIC FERTILIZER EXPERIMENT-GARE ARERA, ETHIOPIA: Field experiments using three types of organic fertilizer, a synthetic fertilizer, and an unfertilized control were conducted on two soil types, in 2002, in Gare Arera ( $9^{\circ} 3^{\prime} \mathrm{N}, 38^{\circ} 30^{\prime} \mathrm{E}$ ) in the Oromiya region of Ethiopia (Tulema et al., 2007). Only the control and the urea fertilizer treatments were included in this data set. The fertilizer rate for the urea treatment was $40 \mathrm{~kg} \mathrm{~N} / \mathrm{ha}$ for the Nitisol soil, and $60 \mathrm{~kg} \mathrm{~N} / \mathrm{ha}$ for the Vertisol soil. The experiments were rainfed. Cultivar DZ-01-354 was planted on July $24^{\text {th }}$ and $25^{\text {th }}$ on the Nitisol and Vertisol soils respectively. Biomass, grain yield, and grain $\mathrm{N}$ were measured at maturity.

8 CALIBRATING THE DSSAT TEF MODEL: The DSSAT Tef model was based on the DSSAT NWheat model, with changes to phenology, photoperiod response, radiation use efficiency, transpiration efficiency and atmospheric $\mathrm{CO}_{2}$ response (Paff and Asseng, 2019). The DSSAT Tef model was calibrated using the field experiments listed above, as well as parameters from the tef literature and from the sorghum literature, whenever there was a gap in the tef literature (Paff and Asseng, 2019). The calibration used all treatments from the experiments in Mekelle, Ilala, and Fallon, NV (Araya et al., 2010; Davison and Laca, 2010). The slow release urea and unfertilized control treatments were used from Asfaw (2012) and Okubay Giday (2012). The Ude 1 and Kajima treatments were used from Tulema (2005). The control and the urea treatment were used from the Tulema (2007) experiment. Certain model parameters, such as radiation use efficiency, transpiration efficiency, and $\mathrm{CO}_{2}$ response, were the same across all cultivars and were derived from values in the tef and sorghum literature (Paff and Asseng, 2019). Individual cultivars were calibrated first for phenology, then for biomass, and finally for grain yield (Paff and Asseng, 2019). The model accurately captured the time to anthesis and maturity for tef, with a root mean square error of 2.5 and 4.4 days respectively (Paff and Asseng, 2019). The model regularly overestimated biomass and grain yields, as it did not account for biological stresses, but did capture the general trends caused by increased irrigation and fertilizer. The relative root mean square error was $49.6 \%$ and $41.0 \%$ for total aboveground biomass and grain yield respectively (Paff and Asseng, 2019).

9 GUIDELINES FOR DATA USE: Details on crop management, weather, soil, and measured crop data are provided in the AgMIP JSON format (Rosenzweig et al., 2013). Table 5 lists the file names for input and measured data for each experiment location used for calibrating the DSSAT Tef model. All data are in text files. The file named Readme_Variable definition.txt defines the parameters and units used. 


\begin{tabular}{|c|c|c|c|c|c|}
\hline \multirow[t]{2}{*}{ Location } & \multirow{2}{*}{ Latitude/Longitude } & \multirow[b]{2}{*}{ Weather } & \multicolumn{2}{|c|}{ Input files } & \multirow[t]{2}{*}{ Observed data } \\
\hline & & & Soil & Management & \\
\hline $\begin{array}{l}\text { Mekelle, } \\
\text { Ethiopia, } \\
2008\end{array}$ & $13.05 \mathrm{~N} / 39.1 \mathrm{E}$ & ETMK0801 & MK & CM_ETMK0801 & $\begin{array}{l}\text { Exp_Mekelle, Exp } \\
\text { _Mekelle_TimeSeries }\end{array}$ \\
\hline $\begin{array}{l}\text { Mekelle, } \\
\text { Ethiopia, } \\
2009\end{array}$ & $13.05 \mathrm{~N} / 39.1 \mathrm{E}$ & ETMK0901 & MK & CM_ETMK0901 & $\begin{array}{l}\text { Exp_Mekelle, Exp } \\
\text { _Mekelle_TimeSeries }\end{array}$ \\
\hline $\begin{array}{l}\text { Ilala, } \\
\text { Ethiopia }\end{array}$ & $13.07 \mathrm{~N} / 39.07 \mathrm{E}$ & ETIL0801 & IL & CM_ETIL0801 & $\begin{array}{l}\text { Exp_Ilala, Exp } \\
\text { Ilala_TimeSeries }\end{array}$ \\
\hline $\begin{array}{l}\text { Fallon, } \\
\text { NV, USA }\end{array}$ & $39.46 \mathrm{~N} /-118.78 \mathrm{~W}$ & FNUS0901 & $\mathrm{FN}$ & CM_USFN0901 & $\begin{array}{l}\text { Exp_Fallon, Exp } \\
\text { Fallon TimeSeries }\end{array}$ \\
\hline $\begin{array}{l}\text { Jamma } \\
\text { District, } \\
\text { Ethiopia }\end{array}$ & $10.45 \mathrm{~N} / 39.25 \mathrm{E}$ & ETJA1101 & JD & CM_ETJD1101 & $\begin{array}{l}\text { Exp_Jamma, Exp } \\
\text { _Jamma_TimeSeries }\end{array}$ \\
\hline $\begin{array}{l}\text { Ofla } \\
\text { District, } \\
\text { Ethiopia }\end{array}$ & $12.5 \mathrm{~N} / 39.52 \mathrm{E}$ & ETON1101 & OD & CM_ETOD1101 & $\begin{array}{l}\text { Exp_Ofla, Exp } \\
\text { _Ofla_TimeSeries }\end{array}$ \\
\hline $\begin{array}{l}\text { Ude, } \\
\text { Ethiopia }\end{array}$ & $8.8 \mathrm{~N} / 39.63 \mathrm{E}$ & EADA9701 & UD & CM_ETUD9701 & $\begin{array}{l}\text { Exp_Ada, Exp } \\
\text { Ada_TimeSeries }\end{array}$ \\
\hline $\begin{array}{l}\text { Kajima, } \\
\text { Ethiopia }\end{array}$ & $8.8 \mathrm{~N} / 39.63 \mathrm{E}$ & EADA9701 & KJ & CM_ETUD9701 & $\begin{array}{l}\text { Exp_Ada, Exp } \\
\text { Ada_TimeSeries }\end{array}$ \\
\hline $\begin{array}{l}\text { Gare } \\
\text { Arera, } \\
\text { Ethiopia, } \\
\text { Nitisol }\end{array}$ & $9.05 \mathrm{~N} / 38.5 \mathrm{E}$ & EGAR0201 & GN & CM_ETGA0201 & $\begin{array}{l}\text { Exp_GareArera, Exp } \\
\text { _GareArera_TimeSeries }\end{array}$ \\
\hline $\begin{array}{l}\text { Gare } \\
\text { Arera, } \\
\text { Ethiopia, } \\
\text { Vertisol }\end{array}$ & $9.05 \mathrm{~N} / 38.5 \mathrm{E}$ & EGAR0201 & GV & CM_ETGA0201 & $\begin{array}{l}\text { Exp_GareArera, Exp } \\
\text { _GareArera_TimeSeries }\end{array}$ \\
\hline
\end{tabular}

\section{REFERENCES}

Araya, A., Keesstra, S. and Stroosnijder, L., 2010. Simulating yield response to water of Teff (Eragrostis tef) with FAO's AquaCrop model. Field Crops Research, 116(1-2): 196-204. doi: 10.1016/j.fcr.2009.12.010

Asfaw, A.G., 2012. Soil Characterization and Evaluation of Slow Release Urea Fertilizer Rates on Yield Components and Grain Yields of Wheat and Teff on Vertisols of Jamma District of South Wollo Zone, Amhara Region, Haramaya University, Haramaya, Ethiopia, 86 pp.

Davison, J. and Laca, M., 2010. Grain Production of 15 Teff Varieties in Churchill County, Nevada During 2009. University of Nevada Cooperative Extension. url: www.unce.unr.edu/publications/files/ag/2010/fs1036.pdf

NRCS, U., 2016. Web Soil Survey. USDA NRCS. url: websoilsurvey.nrcs.usda.gov/app/HomePage.htm

Okubay, G., 2012. Soil Fertility Characterization and Response of Wheat (Triticum aestivum)and Tef (Eragrostis tef) to Different Rates of Slow Release and Conventional Urea Fertilizer in Vertisols of Ofla District, Southern Tigray, Ethiopia, Haramaya University, Haramaya, Ethiopia, 91 pp.

Paff, K. and Asseng, S., 2019. A crop simulation model for tef (Eragrostis tef (Zucc.) Trotter). Agronomy, 2019, 9, 817, doi: 10.3390/agronomy9120817

Rosenzweig, C. et al., 2013. The Agricultural Model Intercomparison and Improvement Project (AgMIP): Protocols and pilot studies. Agricultural and Forest Meteorology, 170: 166-182. doi: 10.1016/j.agrformet.2012.09.011

Tulema, B., Aune, J. and Breland, T., 2007. Availability of organic nutrient sources and their effects on yield and nutrient recovery of tef [Eragrostis tef (Zucc.) Trotter] and on soil properties. Journal of Plant 
Paff et al. 2019, Open Data Journal for Agricultural Research, vol. 6, p. 8-13

Nutrition and Soil Science-Zeitschrift Fur Pflanzenernahrung Und Bodenkunde, 170(4): 543-550. doi: 10.1002/jpln.200521781

Tulema, B., Zapata, F., Aune, J. and Sitaula, B., 2005. N fertilisation, soil type and cultivars effects on N use efficiency in tef [Eragrostis tef (Zucc.) Trotter]. Nutrient Cycling in Agroecosystems, 71(2): 203211. doi: $10.1007 / \mathrm{s} 10705-004-5083-1$ 